\title{
Impact of Tourism on Economic Growth of Nepal: Is Tourism-Led Growth Hypothesis Valid for Nepal?
}

\author{
Kumar Bhattarai \\ Department of Economics, Patan Multiple Campus, TU \\ bhattarai1000@gmail.com \\ Roshan Karmacharya \\ Department of Management, Jana Bhawana Campus, TU \\ roshankarmacharya044@gmail.com
}

\section{Article History}

Received: 22 November, 2021

Accepted: 9 December, 2021

\section{Keywords}

Economic growth, Nepal, Tourism, Tourism-led growth hypothesis, Tourism receipts

Corresponding Editor

Ramesh Raj Kunwar

kunwar.dr@gmail.com

\begin{abstract}
A voluminous study is available on tourism-growth nexus as tourism industry received considerable attention as a potential source of economic growth. This paper empirically examines the impact of tourism on economic growth of Nepal by using time series data of 1976-2020 and applying autoregressive distributed lag (ARDL) approach. Real GDP was used as proxy measure of economic growth, which was the outcome variable whereas the variable of interest was tourism receipts. Foreign aid, total volume of trade and ratio of government consumption expenditure to GDP were taken as control variables. The result of ARDL model shows that tourism has no significant impact on economic growth of Nepal in both short-run and long-run. However, total volume of trade has positive and significant effect on economic growth in shortrun whereas foreign aid, total volume of trade and ratio of government consumption expenditure to GDP have positive and significant effect on economic growth in the long-run. In such context of tourism and growth relationship, tourism-led growth hypothesis is rejected for Nepal.
\end{abstract}




\section{Introduction}

Tourism is potential source of economic growth in many countries. It can be a tool for increasing export revenue, generating employment opportunities, enlarging consumer markets and diversifying economy (Barros et al., 2011; Belloumi, 2010; Fauzel et al., 2016; Mansfeld and Winckler, 2008; Saleh et al., 2015; Tan et al., 2002). Furthermore, it also contributes to government revenue. It has spin-off effect on all sectors of the economy (Saleh et al., 2015). Globally, tourism industry continuously grew over 2010-2019 and it was third largest export category, after chemicals and fuels, in 2017 (United Nations World Tourism Organization [UNWTO], 2020; UNWTO, 2021a). However, international tourist arrival decreased by $73.1 \%$ in 2020 compared to 2019 (UNWTO, 2021b) due to corona virus disease 2019 (COVID-19) pandemic. Neglecting the period of COVID-19 pandemic, as it is exceptional period, tourism is one of the fastest growing sectors of global economy. Increased income and air connectivity are contributing to expand global tourism. With the increase in role of tourism on global economy, empirical studies on the impact of tourism on growth, employment and foreign exchange earnings are also increasing. Studies have found that tourism contributes to economic growth (Balaguer \& Cantavella-Jorda, 2002; Cannonier \& Burke, 2018; Gunduz \& Hatemi-J, 2006; Neuts, 2019). Brida et al. (2014), by reviewing approximately 100 published empirical papers, found that, with few exceptions, tourism-led growth hypothesis is confirmed in the studied countries. Due to this reason development of tourism industry is in priority of the countries. In developed countries, tourism is proved as vital component of their economy and wellbeing whereas developing countries also became successful to improve their economic profile through the expansion of their tourism industry (Khizindar, 2012). For many countries, which have lower competitiveness on export of other goods and services, tourism provides opportunity to reduce their trade deficit.

Nepal has big potential on tourism development as it contains many natural and historical sites. It contains Lumbini (birthplace of Lord Buddha), which is likely to be destination of Buddhist pilgrims from all over the world. Nepal is popular for mountaineering as it contains world renowned mountain peaks including Mount Everest (highest peak of the world), Kanchenjunga, Lhotse, Makalu, among others. There are 8 mountain peaks, having height higher than 8,000 meter, in Nepal. It should be noted that there are only 14 such mountain peaks in the world that have height higher than 8,000 meter. Furthermore, Nepal is rich in cultural and religious diversity and biodiversity as well. Nepal is rich in cultural heritage-both tangible and intangible. All these things make Nepal an attractive tourist destination.

Government of Nepal has established Nepal tourism board for the development, expansion and promotion of tourism in Nepal (Nepal Tourism Board Act, 1997). Tourism Act (1978) and Tourism Policy (2008) constitute legal foundation for the 
arrangement of Nepalese tourism. Tourism Act (1978) aims to benefit general people through tourism development. This act explains the provisions related to issues of tourism industry, like travel and trekking agencies; tourist standard hotels, lodges, restaurant and bar; mountaineering; tour guide; among others. Government of Nepal has given top priority to tourism industry. Tourism policy (2008) aims to promote tourism so that it can act as a foundation for economic transformation of country. Similarly, government is implementing national tourism strategic plan (NTSP), 2016-2025 (Ministry of Culture, Tourism and Civil Aviation [MOCTCA], 2016). Despite such efforts of government of Nepal, the contribution of tourism on Nepalese economy is still low. There is no significant increase in contribution of tourism on foreign exchange earnings and employment in Nepal over the time (Bhattarai et al., 2021). Within the period of 2011-2019, the average ratio of foreign currency earned from tourism to GDP was $1.87 \%$ only (MOCTCA, 2021).

Nepal is facing huge deficit in international trade. This is due to low level of competitiveness of Nepalese goods and services in national as well as international market. Increasing export is a challenging issue for Nepal. In such situation, tourism might be a vehicle for reducing trade deficit. Government had announced 2020 as visit Nepal year which was later on canceled due the outbreak of COVID-19. In such situation, it is important to analyze the impact of tourism on Nepalese economy. A voluminous study is available on tourism-growth nexus in different countries as tourism industry received considerable attention as a potential source of economic growth. But, in case of Nepal, such studies are extremely scanty in spite of government's priority on tourism sector. This study attempts to bridge up this gap and contributes to the literature related to link between tourism and economic growth. More specifically, objective of this study is to analyze the impact of tourism on economic growth of Nepal. This study does not consider domestic tourism. Due to lack of time-series data related to domestic tourism, analysis was focused on international tourism only.

This paper consists of six sections. Section 1 introduces the study. It highlights the importance of study and defines the objective. Section 2 reviews the literature related to the relationship between tourism and economic growth. Section 3 describes the current scenario of Nepalese tourism. Section 4 explains the methodology employed in the study. Section 5 presents the results and discusses them. Section 6 concludes the study.

\section{Literature review}

Basically, there are two hypotheses explaining tourism-economic growth linkage. The first is tourism-led growth hypothesis (TLGH). Explained by Balaguer and Cantavella-Jorda (2002), this hypothesis argues that tourism leads to long-run 
economic growth. It is because tourism brings foreign currency, which can be used to import capital goods. Capital goods is necessary to produce other goods and services, leading to economic growth in the country. This hypothesis suggests unidirectional relationship between tourism and economic growth. A number of studies have supported this hypothesis, including Arslanturk et al. (2011), Gunduz and Hatemi-J (2006), Hye and Khan (2012) and Salifou and Haq (2016). However, some studies have reported no long-run tourism-economic growth nexus but positive impact of tourism on growth in the short-run only (Oh, 2005; Singh et al., 2010). The second hypothesis is economic-driven tourism growth, which argues that economic growth, leads to tourism expansion. Some studies, like Oh (2005) found positive impact of economic growth on tourism expansion. Furthermore, there are some other evidences suggesting bidirectional relationship between tourism and economic growth, like Dogru and Bulut (2018) and Ridderstaat et al. (2014).

Pan and Dossou (2019), by using time-series data of 1995-2015 for Republic of Benin, found positive and significant relationship between tourism and economic growth in short-run (at 10\%) as well as in long-run (at 5\%). Cannonier and Burke (2018) studied impact of tourism on economic growth in 15 Caribbean countries by using panel data of 1980-2015. Study found positive and significant impact of tourism on economic growth. Fauzel et al. (2016), by using time-series data of 19842014 for Mauritius, found that tourism and non-tourism FDI and tourism receipts had positive and significant impact on economic growth. Salifou and Haq (2016) examined the validity of tourism-led growth hypothesis for 11 countries of Economic Community of West African States (ECOWAS). Authors concluded that tourism-led growth hypothesis was valid for this region. Furthermore, Bouzahzah and Menyari (2013) examined the impact of tourism on economic growth of Morocco and Tunisia using time-series data of 1980-2010. Study found positive impact of tourism receipts on GDP growth in short-run for both Morocco (at 5\%) and Tunisia (at 1\%). On the other hand, long-term results suggest that tourism had no significant impact on real GDP growth rate for Tunisia whereas there was significant impact (at 10\%) for Morocco. Srinivasan et al. (2012) found that tourism had positive impact on economic growth in Sri Lanka in short-run as well as in long-run. Such positive impact of tourism was extremely low in short-run compared to long-run. Gautam (2011) found that there was short-term dynamic relationship as well as long-run cointegrating relationship between tourism income and GDP in Nepal. Dritsakis (2004) found that international tourism earnings had caused economic growth in Greece for the period 1960-2000. Durbarry (2004) found, by using time-series data of 1970-1999 in Mauritius, positive and significant effect of real tourism receipts per tourist on economic growth. Balaguer and Cantavella-Jorda (2002) examined role of tourism on long-run economic growth of Spain by using data of 1975-1997. Balaguer 
and Cantavella-Jorda pioneered tourism-led growth hypothesis through this study. Authors found that tourism had positively affected Spanish economic growth over time. Authors concluded that tourism-led growth hypothesis was valid for Spain.

\section{Current scenario of Nepalese tourism}

Nepal was opened to foreign tourists after 1951 (MOCTCA, 2016). MOCTCA has published tourism statistics of 57 years, i.e. from 1964 to 2020 (MOCTCA, 2021). In 1964, the number of tourist arrival was 9,526; which increased to $1,197,191$ in 2019. But, in 2020, it decreased to 230,085. Data suggest that, average annual growth rate of tourist arrival within this period was 10.29\%. Over 1966-1980, there was continuous increase in tourist arrival in Nepal. After that, within 1981-1993, there was fluctuation in tourist arrival. Again, over the period of 1994-1999, there was continuous increase in tourist arrival. Over 2000-2015, there was again instability in tourist arrival. Since 2016 to 2019, there was continuous increase in tourist arrival. In 2020, it decreased. Over the period of 1964-2020, highest growth rate was $53.7 \%$ in 1989. Tourist arrival declined in 1965, 1981, 1984, 1993, 2000, 2001, 2002, 2005, 2008, 2013, 2014, 2015 and 2020. The major decline in tourist arrival seems to be occurred in Maoist insurgency period (i.e. 2000, 2001, 2002 and 2005) and during COVID-19 pandemic (i.e. 2020). The decline in tourist arrival in 2008 was due to global economic meltdown. However, decline in 2013 and 2014 were unexpected whereas decline in 2015, it was due to earthquake and economic blockade imposed by India. Clearly, Nepalese tourism industry is volatile. In the past, it fluctuated due to domestic as well international reasons.

Table 1: Tourist arrival, growth of tourist arrival and length of stay in last ten years (2011-2020)

\begin{tabular}{|l|c|c|c|}
\hline Year & Tourist arrival & Growth rate (\%) & Length of stay \\
\hline 2011 & 736,215 & 22.1 & 13.12 \\
\hline 2012 & 803,092 & 9.1 & 12.16 \\
\hline 2013 & 797,616 & -0.7 & 12.60 \\
\hline 2014 & 790,118 & -0.9 & 12.44 \\
\hline 2015 & 538,970 & -32.0 & 13.16 \\
\hline 2016 & 753,002 & 40.0 & 13.4 \\
\hline 2017 & 940,218 & 25.0 & 12.6 \\
\hline 2018 & $1,173,072$ & 25.0 & 12.4 \\
\hline 2019 & $1,197,191$ & 2.1 & 12.7 \\
\hline 2020 & 230,085 & -80.7 & 15.1 \\
\hline Average & & 0.9 & 12.97 \\
\hline
\end{tabular}

Source: MOCTCA (2021) 
Table 1 shows tourist arrival, its growth rate and length of stay over 2011-2020. There was fluctuation in tourist arrival over this period. There was continuous improvement in tourist arrival over the period 2016-2019. In 2020, there was significant fall in tourist arrival due to COVID-19. Average annual growth rate of tourist arrival for the period of 2011-2020 is 0.9\%. Similarly, there is minor fluctuation in length of stay. Data suggest that, within the period of 1964-2020, length of stay was highest in 2020. The reason behind this is that tourists could not return to their countries due to the restriction imposed in international air transportation caused by COVID-19.

Tourism is one of the worst affected sectors from novel corona virus disease 2019 (COVID-19). Nepal had launched visit Nepal 2020 campaign in January with the expectation of attracting 2 million tourists. But, due to the outbreak of COVID-19 government has cancelled the campaign. Nepal was on lockdown from March $24-$ July 21, 2020, which brought the economy to a standstill. Meanwhile, thousands of workers working in tourism industry lost their job. These workers were working in hotels, travel agency, trekking agency, rafting agency, tourist transportation service, airlines and home stay, among others. Similarly, entrepreneurs involving in tourism business lost their income. With the halt in tourist inflow, foreign exchange earnings from tourism have negatively affected. It is still uncertain that when this pandemic will over.

\section{Methodology}

\section{Model specification}

This study analyzes relationship between tourism and economic growth in Nepal. Gross domestic product (GDP) was used as proxy measure of economic growth, which was the outcome variable whereas the variable of interest was tourism receipts (TR). Foreign aid (FA), total volume of trade (TRD) and ratio of government consumption expenditure to GDP were control variables. All variables were measured in constant 2010/11 rupees. Based on existing literature (Balagure \& Cantavella-Jorda, 2002; Cannonier \& Burke, 2018; Fauzel et al., 2016; Saleh et al., 2015) analytical model was developed as follows:

$$
\mathrm{GDP}=\mathrm{f}(\mathrm{TR}, \mathrm{FA}, \mathrm{TRD}, \mathrm{GC} / \mathrm{GDP})
$$

Study was based on secondary sources of information. Data were taken from MOF (2021) and MOCTCA (2021). Analysis was based on time-series data of 19762020 .

\section{Estimation issues}

\section{Unit root test}

In order to test whether time series is stationary, Augmented Dickey Fuller unit root test was carried out, as explained by Asteriou and Hall (2007), as follows: 
The general equations for the $\mathrm{ADF}$ test are:

$$
\Delta \mathrm{Y}_{\mathrm{t}}=\alpha_{0}+\alpha_{1} \mathrm{t}+\gamma \mathrm{Y}_{\mathrm{t}-1}+\sum_{\mathrm{i}=1}^{\mathrm{p}} \beta_{\mathrm{i}} \Delta \mathrm{Y}_{\mathrm{t}-1}+\mu_{\mathrm{t}}
$$

Where, $Y_{t}$ is a time series variable, $\alpha_{0}$ is a constant, $\alpha_{1}$ is the coefficient on a time trend $(t)$, is coefficient of lagged variable, are the coefficients of difference of lagged variable, $\mathrm{p}$ is the lag order of the autoregressive process and $\mu_{\mathrm{t}}$ is a pure white noise error term.

\subsubsection{Cointegration: ARDL bounds test}

Auto-regressive distributed lag model (ARDL) bounds test was employed as explained by Pesaran, Shin and Smith (2001) as the variables are stationary at level and $1^{\text {st }}$ difference. The effect of explanatory variables on dependent variable may not be immediate or instant; it may take time to show the effect of the independent variables on the dependent variable. Autoregressive distributed lag (ARDL) approach of cointegration is the appropriate econometric approach to capture the lagged effect of the explanatory variables on the dependent variable. ARDL regression involves two stages: in the first stage the existence of a long-run relationship between the variables is tested and in the second stage the parameters of long-run and short-run is estimated. In this study, Akaike information criteria have been used to choose the optimal lag lengths.

All the variables are taken in natural logarithm. The basic model used for the estimation is specified as:

$$
\ln G D P_{t}=a+b_{1} \ln F A_{t}+b_{2} \ln T R_{t}+b_{3} \ln T R D_{t}+b_{4} \ln (G C / G D P)_{t}+\mu_{t}
$$

Where,

$$
\begin{array}{lll}
\operatorname{lnGDP} & =\text { GDP of Nepal expressed in logarithm } \\
\operatorname{lnFA_{t}} & =\text { Foreign aid received expressed in logarithm } \\
\operatorname{lnTR} R_{t} & =\text { Receipts from tourism expressed in logarithm } \\
\operatorname{lnTRD} & =\text { Trade volume expressed in logarithm } \\
\ln (\mathrm{GC} / \mathrm{GDP}) & =\begin{array}{l}
\text { Ratio of government consumption expenditure to GDP } \\
\end{array} \\
\mathrm{a} & =\text { expressed in logarithm } \\
\mathrm{b}_{\mathrm{i}} \mathrm{s} & =\text { Respective coefficients } \\
\mu_{\mathrm{t}} & =\text { Error term }
\end{array}
$$

Following Pesaran, Shin and Smith (2001), ARDL representation of unrestricted version is specified as: 


$$
\begin{aligned}
\Delta \ln G D P_{t}=u & +\sum_{i=0}^{m} \eta_{i} \Delta G D P_{t-1}+\sum_{i=0}^{n} \omega_{i} \Delta \ln F A_{t-i}+\sum_{i=0}^{p} \varphi_{i} \Delta \ln T R_{t-i}+\sum_{i=0}^{q} \pi_{i} \Delta \ln T R D_{t-i} \\
& +\sum_{i=0}^{r} \rho_{i} \Delta \ln G C / G D P_{t-i}+\theta_{1} \ln G D P_{t-1}+\theta_{2} \ln F A_{t-1}+\theta_{3} \ln T R_{t-1} \\
& +\theta_{4} \ln T R D_{t-1}+\theta_{5} \ln \left(\frac{G C}{G D P}\right)_{t-1}+\mu_{t}
\end{aligned}
$$

Where $\Delta$ denotes first difference operator, $\mathrm{u}$ is the intercept term and is the usual white noise residual.

In the ARDL model, the coefficients $\left(\theta_{1}\right.$ to $\left.\theta_{5}\right)$ represent the long-run relationship whereas the remaining expressions with summation sign (coefficients $\eta_{i}, \omega_{i}, \varphi_{i}, \pi_{i}, \rho_{i}$ ) represent the short- run dynamics of the model.

\section{Results and Discussion}

The analysis proceeds by making unit root test of variables. Later part contains the ARDL model including short-run and long-run relationships. Different residuals and stability test have been shown in order to check the viability of the model.

\section{Unit root test of variables}

The result of the Augmented Dickey-Fuller test of the time series is given in table 4 .

Table 4: Augmented Dickey-Fuller test

\begin{tabular}{|l|l|l|l|}
\hline Variables & Stationary at & Includes & p-value \\
\hline $\operatorname{lnGDP}$ & 1st difference & intercept only & 0.0000 \\
\hline $\ln \mathrm{FA}$ & 1st difference & intercept only & 0.0000 \\
\hline $\operatorname{lnTR}$ & 1st difference & intercept only & 0.0000 \\
\hline $\operatorname{lnTRD}$ & 1st difference & intercept only & 0.0000 \\
\hline $\operatorname{lnGC}$ & level & trend and intercept & 0.0351 \\
\hline
\end{tabular}

Source: Authors' estimation in Eviews 10

From the Table 4 , it can be seen that all the variables are stationary at $1^{\text {st }}$ difference at $1 \%$ level of significance, which include only intercept term except for government consumption expenditure, which is stationary at level at $5 \%$ level of significance including both trend and intercept term.

\section{ARDL model for cointegration test}

The results of first stage of the ARDL method of cointegration test for the determinants are given in Table 5. Here, the dependent variable is $\ln$ GDP with 45 observations used for the estimation from 1976 to 2020. 
Table 5: Autoregressive distributed lag estimates

Model: $\ln G D P=f(\ln F A, \ln T R, \ln T R D, \ln G C / G D P)$

ARDL $(4,1,0,2,3)$ selected based on Akaike information criteria (AIC)

\begin{tabular}{|c|c|c|c|c|}
\hline Variable & Coefficient & Std. Error & t-Statistic & Prob. \\
\hline $\operatorname{lnGDP}(-1)$ & -0.1935 & 0.1527 & -1.2670 & 0.2164 \\
\hline $\operatorname{lnGDP}(-2)$ & 0.3105 & 0.1238 & 2.5090 & 0.0187 \\
\hline $\operatorname{lnGDP}(-3)$ & 0.3759 & 0.1069 & 3.5160 & 0.0016 \\
\hline $\operatorname{lnGDP}(-4)$ & 0.3706 & 0.1171 & 3.1649 & 0.0039 \\
\hline $\operatorname{lnFA}$ & -0.0156 & 0.0230 & -0.6793 & 0.5030 \\
\hline $\operatorname{lnFA}(-1)$ & 0.0811 & 0.0258 & 3.1442 & 0.0041 \\
\hline $\operatorname{lnTR}$ & -0.0017 & 0.0101 & -0.1669 & 0.8687 \\
\hline $\operatorname{lnTRD}$ & 0.1389 & 0.0299 & 4.6440 & 0.0001 \\
\hline $\operatorname{lnTRD}(-1)$ & 0.0002 & 0.0401 & 0.0054 & 0.9957 \\
\hline $\operatorname{lnTRD}(-2)$ & -0.0910 & 0.0314 & -2.8928 & 0.0076 \\
\hline $\operatorname{lnGC/GDP}$ & 0.0331 & 0.0278 & 1.1893 & 0.2451 \\
\hline $\operatorname{lnGC/GDP}(-1)$ & 0.0350 & 0.0324 & 1.0811 & 0.2896 \\
\hline $\operatorname{lnGC/GDP}(-2)$ & 0.0112 & 0.0343 & 0.3254 & 0.7475 \\
\hline $\ln G C / G D P(-3)$ & 0.1060 & 0.0280 & 3.7827 & 0.0008 \\
\hline $\mathrm{C}$ & 1.1833 & 0.3180 & 3.7211 & 0.0010 \\
\hline R-squared & 0.9996 & \multirow{3}{*}{\multicolumn{2}{|c|}{$\begin{array}{l}\text { Akaike info criterion } \\
\text { Durbin-Watson stat } \\
\text { Prob(F-statistic) }\end{array}$}} & -5.6792 \\
\hline Adjusted R-squared & 0.9994 & & & 2.0296 \\
\hline F-statistic & 5004.9110 & & & 0.0000 \\
\hline
\end{tabular}

Source: Authors' estimation in Eviews 10

Table 5 shows the best autoregressive distributed lag model automatically selected by the Eviews 10 based on the Akaike information criteria. The coefficients of lnFA, $\operatorname{lnTR}, \ln T R D$ and $\operatorname{lnGC/GDP}$ represent short-run coefficients. The coefficients of $\ln F A, \ln T R$ and $\operatorname{lnGC/GDP}$ are not statistically significant while coefficient of $\operatorname{lnTRD}$ is positive and statistically significant. The coefficient is 0.1389 , which means that in the short-run, $1 \%$ increase in trade volume leads to $0.1389 \%$ increase in GDP. The $\mathrm{R}^{2}$ and adjusted $\mathrm{R}^{2}$ is 0.99 which means that $99 \%$ of the variation in dependent variable is explained by the independent variables. 
Table 6: Testing for existence of a level relationship among the variables in the ARDL model

\begin{tabular}{|c|c|c|c|c|}
\hline Test Statistic & Value & Significance & $\mathbf{I}(\mathbf{0})$ & $\mathbf{I}(\mathbf{1})$ \\
\hline F-statistic & 16.1019 & $10 \%$ & 2.2 & 3.09 \\
\hline \multirow{2}{*}{ K } & \multirow{2}{*}{4} & $5 \%$ & 2.56 & 3.49 \\
& & $2.50 \%$ & 2.88 & 3.87 \\
& & $1 \%$ & 3.29 & 4.37 \\
\hline
\end{tabular}

Source: Authors' estimation in Eviews 10

Table 6 shows that the F-statistic is 16.1019 , which is greater than the upper bound at all three level of significance which means that there exists long-run relationship among dependent variable and independent variables. Hence, it implies that the variables of the model have a tendency of moving together over time.

Table 7: Estimated long-run coefficients using ARDL approach

\begin{tabular}{|l|c|c|c|c|}
\hline Variable & Coefficient & Std. Error & t-Statistic & Prob. \\
\hline $\ln \mathrm{FA}$ & 0.4797 & 0.1824 & 2.6299 & 0.0142 \\
\hline $\ln \mathrm{TR}$ & -0.0123 & 0.0735 & -0.1679 & 0.8680 \\
\hline $\ln \mathrm{TRD}$ & 0.3527 & 0.0955 & 3.6927 & 0.0010 \\
\hline $\ln \mathrm{GC} / \mathrm{GDP}$ & 1.3580 & 0.3545 & 3.8307 & 0.0007 \\
\hline $\mathrm{C}$ & 8.6729 & 1.6867 & 5.1419 & 0.0000 \\
\hline
\end{tabular}

Source: Authors' estimation in Eviews 10

The estimated long-run coefficients of $\operatorname{lnFA}$, lnTRD and $\ln$ GC/GDP are positive and also statistically significant, which indicates that there is positive relationship between GDP and independent variables except lnTR. The coefficient of $\operatorname{lnFA}$ is 0.4797 , which means that $1 \%$ increase in foreign aid leads to $0.4797 \%$ increase in GDP. The coefficient of lnTRD is 0.3527 which means that $1 \%$ increase in TRD leads to $0.3527 \%$ increase in GDP. Similarly, the coefficient of lnGC/GDP is 1.3580 , which means that $1 \%$ increase in ratio of government consumption expenditure to GDP leads to $1.3580 \%$ increase in GDP. But, the coefficient of $\operatorname{lnTR}$ is statistically insignificant which means that there is no relationship between tourism receipts and GDP in case of Nepal. 
Table 8: ARDL error correction regression

ARDL $(4,1,0,2,3)$ selected based on Akaike information criteria (AIC)

\begin{tabular}{|l|c|c|c|c|}
\hline Variable & Coefficient & Std. Error & t-Statistic & Prob. \\
\hline $\mathrm{D}(\operatorname{lnGDP}(-1))$ & -1.0571 & 0.1259 & -8.3943 & 0.0000 \\
\hline $\mathrm{D}(\operatorname{lnGDP}(-2))$ & -0.7465 & 0.0974 & -7.6614 & 0.0000 \\
\hline $\mathrm{D}(\operatorname{lnGDP}(-3))$ & -0.3706 & 0.0966 & -3.8350 & 0.0007 \\
\hline $\mathrm{D}(\operatorname{lnFA})$ & -0.0156 & 0.0185 & -0.8461 & 0.4052 \\
\hline $\mathrm{D}(\operatorname{lnTRD})$ & 0.1389 & 0.0226 & 6.1516 & 0.0000 \\
\hline $\mathrm{D} \operatorname{lnLTRD}(-1))$ & 0.0910 & 0.0265 & 3.4292 & 0.0020 \\
\hline $\mathrm{D}(\operatorname{lnGC/GDP})$ & 0.0331 & 0.0218 & 1.5169 & 0.1414 \\
\hline $\mathrm{D}(\operatorname{lnGC/GDP}(-1))$ & -0.1171 & 0.0267 & -4.3931 & 0.0002 \\
\hline $\mathrm{D}(\operatorname{lnGC/GDP}(-2))$ & -0.1060 & 0.0235 & -4.5159 & 0.0001 \\
\hline CointEq(-1) & -0.1364 & 0.0127 & -10.7324 & 0.0000 \\
\hline
\end{tabular}

Source: Authors' estimation in Eviews 10

Table 8 shows that the coefficient of CointEq(-1) is negative $(-0.1364)$ and statistically significant at $1 \%$ level of significance. It means that there is existence of a cointegrating relationship of the dependent variable lnGDP with the set of its regressors.

\section{Residual tests}

The results of residual test of the ARDL model is given below:

Table 9: Normality test

\begin{tabular}{|l|l|}
\hline Jarque-Bera & 0.0897 \\
\hline Probability & 0.9562 \\
\hline
\end{tabular}

Source: Authors' estimation in Eviews 10

Table 9 shows that p-value of Jarque-Bera test is 0.9562 , which means null hypothesis of normality cannot be rejected. Hence, the residual of the OLS estimate is normal.

Table 10: Breusch-Godfrey serial correlation LM test

\begin{tabular}{|l|l|l|l|}
\hline F-statistic & 0.0504 & Prob. F(2,24) & 0.9510 \\
\hline Obs $^{\star}$ R-squared & 0.1714 & Prob. Chi-Square(2) & 0.9179 \\
\hline
\end{tabular}

Source: Authors' estimation in Eviews 10

In Table 10 the probability value of Chi-square is 0.9179 , so the null hypothesis cannot be rejected. Therefore, the null hypothesis, that is, there is no serial correlation, cannot be rejected meaning that there is no serial correlation. 
Table 11: Breusch-Pagan-Godfrey heteroskedasticity test

\begin{tabular}{|l|l|l|l|}
\hline F-statistic & 1.9117 & Prob. F(14,26) & 0.0742 \\
\hline Obs $^{\star}$ R-squared & 20.797 & Prob. Chi-Square(14) & 0.107 \\
\hline Scaled explained SS & 8.1089 & Prob. Chi-Square(14) & 0.8836 \\
\hline
\end{tabular}

Source: Authors' estimation in Eviews 10

In Table 11, the probability value of F-Statistic is 0.4329 , which indicates that the null hypothesis, the model is homoscedastic, cannot be rejected. Hence, it can be concluded that model is homoscedastic.

\section{Stability Test}

The results of stability test of the ARDL model is given in table 12:

Table 12: Ramsey RESET test

\begin{tabular}{|l|c|c|c|}
\hline & Value & df & Probability \\
\hline t-statistic & 0.4636 & 25 & 0.6470 \\
\hline F-statistic & 0.2149 & $(1,25)$ & 0.6470 \\
\hline
\end{tabular}

Source: Authors' estimation in Eviews 10

It can be seen that the t-statistic is clearly lower than the critical value 1.96 (at 5\% level of significance). Also, the p-value is 0.6470 , which indicates that null hypothesis cannot be rejected. Hence, model has no any omitted variables.

The stability of the ARDL model is further checked by plotting the cumulative sum of recursive residuals (CUSUM) and the CUSUM of squares (CUSUMSQ). CUSUM involves the calculation of a cumulative sum.

\section{Figure1: CUSUM test}

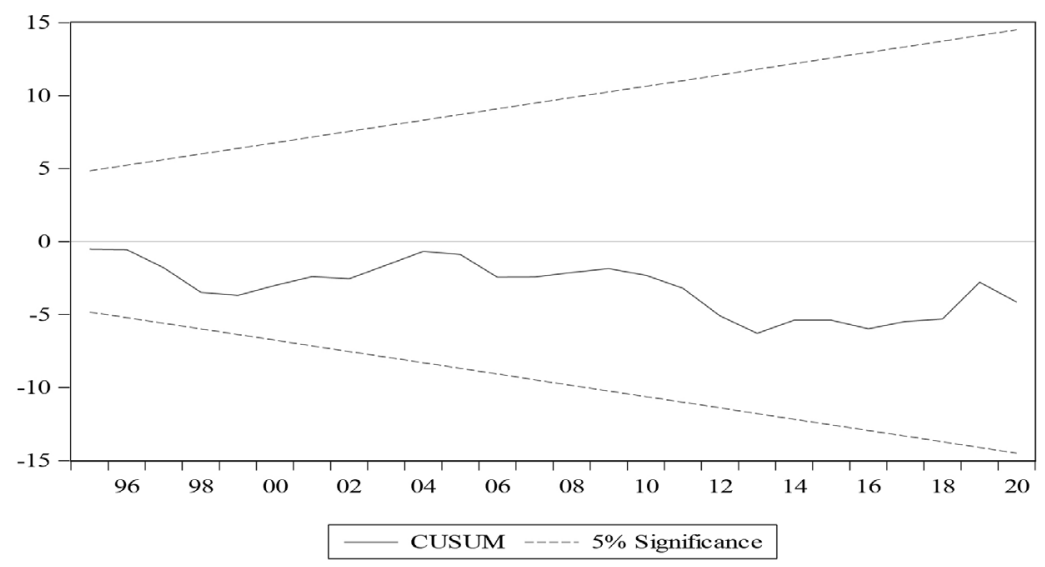

Source: Authors' estimation in Eviews 10 
Similarly, figure 2 shows CUSUMSQ test.

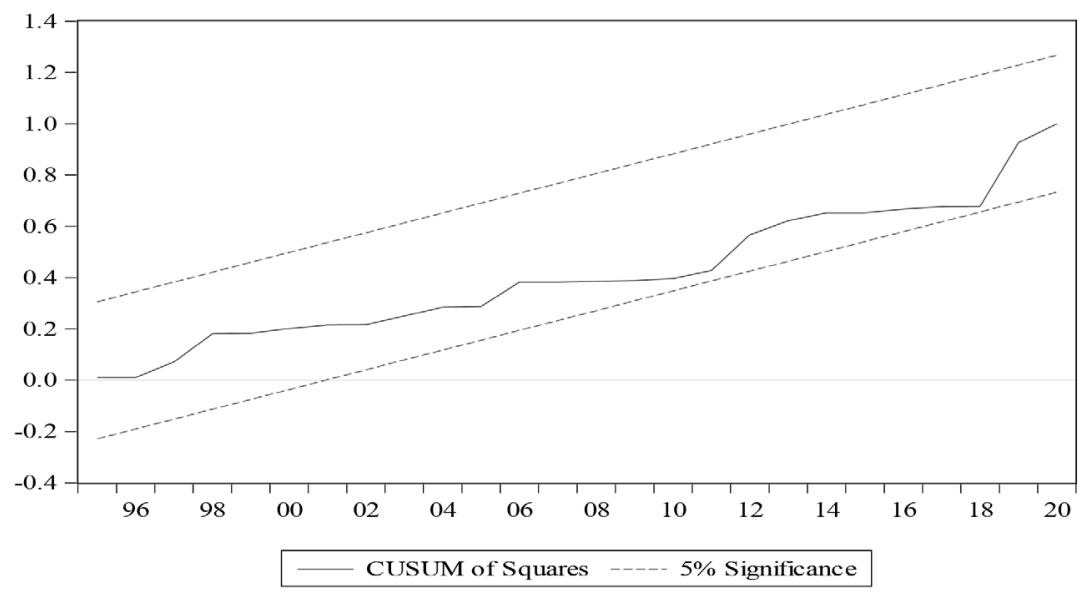

Source: Authors' estimation in Eviews 10

Figure 1 and 2 show the cumulative sum of recursive residuals and cumulative sum of square of recursive residuals respectively, which clearly demonstrate that the CUSUM curve and CUSUMSQ curve lie within the 5\% critical bound lines. So, it can be inferred that the space of the parameters of the OLS model is stable and the model is not mis-specified.

The estimation of ARDL model shows that there is positive and significant relationship between foreign aid, total trade volume and ratio of government consumption expenditure to GDP, and economic growth in the long-run. Asteriou (2009), Gounder (2010), Moreira (2005) and Tarp et al. (2015) also found positive and significant relationship between foreign aid and economic growth. Dollar and Burnside (2016) argue that foreign aid positively influences economic growth of developing countries in the presence of good fiscal, monetary and trade policies. Such evidence on aid and growth relationship is in line with the prediction of neoclassical growth theory. If foreign aid is used in infrastructure development, human resource development and in other productive sectors of economy, it contributes to growth. Furthermore, positive and significant relationship, in the long-run, is found in between total volume of trade and economic growth. Were (2015) also found positive relationship between trade and economic growth. Regarding total volume of trade, import has dominating share. When a country imports capital goods, it increases productive capacity of country. Similarly, import of capital goods promotes development of infrastructure of the country. In this way, trade influences growth positively. Similarly, Moreno et al. (2019) also found positive relationship between government consumption expenditure and economic growth in Colombia. But, there is no long-run relationship between tourism receipts and economic growth. Oh 
(2005) and Ramjee Singh et al. (2010) also found no relationship between tourism receipts and economic growth in the long-run.

\section{Conclusion}

This study analyzed the impact of tourism on economic growth of Nepal. Real GDP was used as proxy measure of economic growth, which was the outcome variable whereas the variable of interest was tourism receipts. Foreign aid, total volume of trade and ratio of government consumption expenditure to GDP were taken as control variables. Autoregressive distributed lag model was employed. Study was based on time series data of 1976-2020. Necessary diagnostic tests were also conducted. Study found that there was no significant relationship between tourism and economic growth in short-run as well as long-run. The reason behind this is that tourism has very low contribution to GDP of Nepal. Over the period of 20112019 , the average ratio of foreign currency earned from tourism to GDP was $1.87 \%$ only. Similarly, daily spending per tourist in 2020 was $\$ 65$ only, which is very low. However, study found that total volume of trade has positive and significant effect on economic growth in short-run whereas foreign aid, total volume of trade and ratio of government consumption expenditure to GDP have positive and significant effect on economic growth in the long-run. In such context of tourism and growth relationship, tourism-led growth hypothesis is rejected for Nepal.

Major problems of Nepalese tourism are low level of tourist arrival and low daily spending per tourist. These are caused by low level of tourism competitiveness of Nepal. In the absence of breakthrough in terms of no. of tourist arrival and their spending, there will be insignificant role of tourism on economic growth of Nepal. Using resources on tourism sector to maintain existing situation only will not create significantly productive result in the country. It will have opportunity cost to the country. In such situation, serious question arises on whether tourism can be a foundation for economic transformation of the country.

\section{Acknowledgement}

This paper is a part of research entitled 'Impact of Tourism on Nepalese Economy', which was conducted by Kumar Bhattarai and Numa Kala Bhusal. The financial support for the study was provided by Ministry of Culture, Tourism and Civil Aviation, Nepal.

\section{References}

Arslanturk, Y., Balcilar, M., \& Ozdemir, Z. A. (2011). Time-varying linkages between tourism receipts and economic growth in a small open economy. Economic Modelling, 28, 664-671. https://dx.doi.org/10.1016/j.econmod.2010.06.003 
Asteriou, D. (2009). Foreign aid and economic growth: New evidence from a panel data approach for five South Asian countries. Journal of Policy Modeling, 31(1), 155-161. https://dx.doi.org/10.1016/j.jpolmod.2008.04.012

Asteriou, D., \& Hall, S. G. (2007). Applied Econometrics: A Modern Approach using Eviews and Microfit. Palgrave Macmillan.

Balaguer, J., \& Cantavella-Jorda, M. (2002). Tourism as a long-run economic growth factor: The Spanish case. Applied Economics, 34, 877-884. https://dx.doi. org/10.1080/000368401/0058923

Barros, C. P., Botti, L., Peypoch, N., \& Solonandrasana, S. (2011). Managerial efficiency and hospitality industry: The Portuguese case. Applied Economics, 43(2), 28952905. https://dx.doi.org/10.1080/00036840802600145

Belloumi, M. (2010). The relationship between tourism receipts, real effective exchange rate and economic growth in Tunisia. International Journal of Tourism Research, 12, 550-560. https://dx.doi.org/10.1002/jtr.774

Bhattarai, K., Upadhyaya, G., \& Bohara, S. K. (2021). Tourism, employment generation and foreign exchange earnings in Nepal. Journal of Tourism and Hospitality Education, 11, 1-21. https://www.researchgate.net/publication/353007584_ Tourism_Employment_Generation_and_Foreign_Exchange_Earnings_in_ Nepal

Bouzahzah, M., \& Menyari, Y. E. (2013). International tourism and economic growth: The case of Morocco and Tunisia. The Journal of North African Studies, 18(4), 592-607. https://dx.doi.org/10.1080/13629387.2013.836321

Brida, J. G., Cortez-Jimenez, I., \& Pulina, M. (2014). Has the tourism-led growth hypothesis been validated? A literature review. Current Issues in Tourism, 19(5), 394-430. https://dx.doi.org/10.1080/13683500.2013.8684/4

Cannonier, C., \& Burke, M. G. (2018). The economic growth impact of tourism in small island developing states-evidence from the Caribbean. Tourism Economics, $X X(\mathrm{X}), 1-24$. https://doi.org/10.1177/1354816618792792

Dogru, T., \& Bulut, U. (2018). Is tourism an engine for economic recovery? Theory and empirical evidence. Tourism Management, 67, 425-434. https://doi.org/10.1016/j. tourman. 2017. 06.014

Dollar, D., \& Burnside, A. C. (2016). Aid, Policies and Growth. SSRN. https://papers. ssrn.com/sol3/papers.cfm?abstract_id $=569252$

Dritsakis, N. (2004). Tourism as a long-run economic growth factor: An empirical investigation for Greece using causality analysis. Tourism Economics, 10(3), 305316. https://doi.org/10.5367/0000000041895094 
Durbarry, R. (2004). Tourism and economic growth: The case of Mauritius. Tourism Economics, 10(4), 389-401. https://doi.org/10.5367/0000000042430962

Fauzel, S., Seetanah, B., \& Sannassee, R. V. (2016). Analyzing the impact of tourism foreign direct investment on economic growth: Evidence from a small island developing state. Tourism Economics, 23(5), 1042-1055. https://doi. org/10.1177/1354816616664249

Gautam, B. P. (2011). Tourism and economic growth in Nepal. NRB Economic Review, 23(2), 18-30. https://nrb.org.np/red/publications/f_/webcrysis/ecorev/NRB_ Economic_Review--Vol_232,_October_2011+2_Tourism_and_Economic_ Growth_in_Nepal\%5BBishnu\%20Prasad\%20Gautam,\%20Ph.D.\%5D.pdf

Gounder, R. (2010). Aid-growth nexus: Empirical evidence from Fiji. Applied Economics, 33(8), 1009-1019. https://doi.org/10.1080/00036840122986

Gunduz, L., \& Hatemi-J, A. (2006). Is the tourism-led growth hypothesis valid for Turkey? Applied Economics Letters, 12(8), 499-504. https://doi. org/10.1080/13504850500109865

Hye, Q. M. A., \& Khan, R. E. A. (2012). Tourism-led growth hypothesis: A case of Pakistan. Asia Pacific Journal of Tourism Research, 18(4), 303-313. https://dx.doi. org/10.1080/10941665.2012.658412

Khizindar, T. M. (2012). Effects of tourism on residents' quality of life in SaudiArabia: An empirical study. Journal of Hospitality Marketing and Management, 21(6), 617-637. https://doi.org/10.1080/19368623.2012.627226

Mansfeld, Y., \& Winckler, O. (2008). The role of tourism industry in transforming a rentier to a long-term viable economy: The case of Bahrain. Current Research in Tourism, 11(3), 237-267. https://doi.org/10.1080/13683500802140307

Ministry of Culture, Tourism and Civil Aviation (MOCTCA). (2016). Nepal Tourism Strategic Plan 2016-2025. MOCTCA.

Ministry of Culture, Tourism and Civil Aviation (MOCTCA). (2021). Nepal Tourism Statistics 2020. MOCTCA.

Moreira, S. B. (2005). Evaluating the impact of foreign aid on economic growth: A cross-country study. Journal of Economic Development, 30(2), 25-49. http:// comum.rcaap.pt/bitstream/10400.26/4464/1/16_2005-Dez_JED_paper.pdf

Moreno, G., Liu, H., \& Mirza, N. (2019). Capital formation, manufacturing productivity, government consumption and economic growth in Colombia: An ARDL bound testing approach. North American Academic Research, 2(3), 1-9. http://twasp.info/journal/archive/1-9.pdf 
Nepal Tourism Board Act. (1997). http://www.lawcommission.gov.np/en/wpcontent/uploads/2018/10/nepal-tourism-board-act-2053-1997.pdf

Neuts, B. (2019). Tourism and urban economic growth: A panel analysis of German cities. Tourism Economics, XX(X), 1-9.https://doi.org/10.1177/1354816619833553

Oh, C. K. (2005). The contribution of tourism development to economic growth in the Korean economy. Tourism Economy, 26, 39-44. https://doi.org/10.1016/j. tourman.2003.09.014

Pan, X., \& Dossou, T. A. M. (2019). The relationship between tourism and sustainable economic growth in the Republic of Benin. Current Issues in Tourism, 23(7), 785794. https://doi.org/10.1080/13683500.2019.1676206

Pesaran, M.H., Shin, Y., \& Smith, R. (2001). Bounds testing approaches to the analysis of level relationships. Journal of Applied Econometrics, 16, 289-326. https://doi. org/10.1002/jae.616

Ridderstaat, J., Croes, R., \& Nijkamp, P. (2014). Tourism and long-run economic growth in Aruba. International Journal of Tourism Research, 16, 472-487. https:// doi.org/10.1002/jtr.1941

Saleh, A. S., Assaf, A. G., Ihalanayake, R., \& Lung, S. (2015). A panel cointegration analysis of the impact of tourism on economic growth: Evidence from the Middle East region. International Journal of Tourism Research, 17, 209-220. https://doi. org/10.1002/jtr.1976

Salifou, C. F., \& Haq, I. U. (2016). Tourism, globalization and economic growth: A panel cointegration analysis for selected West African states. Current Issues in Tourism, 20(6), 664-667. https://doi.org/10.1080/13683500.2016.1175421

Singh, D. R., Wright, A. S., Hayle, C., \& Craigwell, R. (2010). Is the tourism-led growth thesis valid? The case of the Bahamas, Barbados and Jamaica. Tourism Analysis, 15, 435-445. https://doi.org/10.3727/108354210X12864727453223

Srinivasan, P., Santosh Kumar, P. K., \& Ganesh, L. (2012). Tourism and economic growth in Sri Lanka: An ARDL bounds testing approach. Environment and Urbanization ASIA, 3(2), 397-405. https://doi.org/10.1177/0975425312473234

Tan, A. Y. F., McCahon, C., \& Miller, J. (2002). Stability of inbound tourism demand models: The pre-and post-formation of tourism development organizations. Journal of Hospitality and Tourism Research, 26(4), 361-378. https://doi. org/10.1177/109634802237484

Tarp, F., Jones, S., \& Arndt, C. (2015). Assessing foreign aid's long-run contribution to growth and development. World Development, 69, 6-18. https://doi.org/10.1016/j. worlddev.2013.12.016 
Tourism Act. (1978). http://www.lawcommission.gov.np/en/wp-content/ uploads/2018/10/tourism-act-2035-1978.pdf

Tourism Policy. (2008). https://www.tourism.gov.np//files/publication_files/30_ 1503553190.pdf

United Nations World Tourism Organization (UNWTO). (2020). International Tourism Highlights: 2019 Edition. UNWTO.

United Nations World Tourism Organization (UNWTO). (2021a). International Tourism Highlights: 2020 Edition. UNWTO

United Nations World Tourism Organization (UNWTO). (2021b). World Tourism Barometer. UNWTO.

Were, M. (2015). Differential effects of trade on economic growth and investment: A cross-country empirical investigation. Journal of African Trade, 2(1-2), 71-85. https://doi.org/10.1016/j.joat.2015.08.002 